\title{
ВЫБОРЫ В ГОСУДАРСТВЕННУЮ ДУМУ В ОБЛАСТИ ВОЙСКА ДОНСКОГО И ПОЛИТИЧЕСКИЕ ПРЕДПОЧТЕНИЯ ДОНСКОГО ЭЛЕКТОРАТА
}

В статье анализируются региональные особенности выборов в I и II Государственные думы Российской империи в Области войска Донского. Рассмотрены условия и особенности проведения избирательных кампаний на Дону, проанализирована электоральная политика политических партий на выборах в Первую и Вторую Государственные Думы. Показан процесс вовлечения населения Донской области в политический процесс через выборную кампанию. Выявлены особенности формирования политических пристрастий донского электората и факторы, определяющих их выбор. Показана роль политических партий в борьбе за электорат, их влияние на формирование политических предпочтений избирателей. Оппозиционные настроения в обществе, характерные для основной массы донского электората, обеспечили преимущества пропаганде «оппозиционных партий». Сделан вывод о том, что ход предвыборной агитации на Дону раскрывает преимуще- ства конституционных демократов. Автор доказывает что успеху кадетской партии способствовала умелая организация предвыборной борьбы, дополнение местными требованиями общеполитической части программы, разрозненность политических противников, прежде всего правых, их неумение организовать и эффективно провести предвыборную кампанию. Еще успех кадетов зависел от «чувствительности» их к групповым интересам донского электората, в первую очередь - казачьего. Рассмотрен состав областного избирательного собрания, приведены данные о депутатах от области по сословной и политической принадлежности. Показана связь развития политизации в донском обществе с выборным процессом в Думу первых двух созывов.

Ключевые слова: |-ІІ Государственная Дума Российской империи, выборы, Область войска Донского электорат.

\section{STATE DUMA ELECTIONS IN THE PROVINCE OF THE DON COSSACK HOST AND POLITICAL PREFERENCES OF THE DON ELECTORATE}

The article studies regional peculiarities of the Don Cossack Host elections to the First and the Second State Duma of the Russian Empire. The author analyzes the conditions and features of election campaigns in the Don region, the political positions of the parties during the First and the Second State Duma elections, and shows how citizens got involved in the political life through elections. The peculiarities of forming political interests of the Don electorate and political fight for electorate as a factor of influence on the preferences of citizens are also addressed to in the article. It is argued that opposition sentiments of the society, typical of the greater part of the Don electorate, gave advantages to the "opposition parties" and their propaganda. The author concludes that agitation process showed superiority of Constitutional Democrats. On the one hand, the success of the party due to efficient organization of electoral company

Локальные исследования истории выборов в Российской империи начала $X X$ века помогают уточнить общие представления о поведении электората, об особенностях процесса формирования их политических предпочтений. Обращение к истории выборной кампании на Дону расширяет возможности анализа общих и специфических мотивов поведения различных групп избирателей. Подробный анализ позволяет раскрыть кон- and reflection of the local needs of people in their political program. On the other hand, the discord of their political rivals, and the disability to organize and conduct the campaign at a high level proved to be important reasons for the fail. The success of Constitutional Democrats depended on their understanding of group interests of the Don electorate Cossacks in particular. The article studies the composition of the regional electoral assembly. The author also gives the information about the deputies from the region with their class and political affiliations, and shows the connection between the development of the Don society politicization and the election process in the Duma of the first two convocation.

Key words: the First and the Second State Duma of the Russian Empire, elections, the Don Cossack Host, electorate.

кретно-исторический контекст проведения кампании по выборам в Государственную думу, участия и влияния на нее различных политических сил в Области войска Донского (далее - ОВД)

В исторической литературе достаточно полно изучены общероссийская предвыборная компания перед выборами в Государственную Думу начала XX в. и её результаты. Менее исследованы особенности выборов в Российской провинции. 
Выборы в ОВД в Государственную думу начала XX в. затрагивались лишь в исследованиях по политической истории Донского региона [3-6, 26] Однако в работах избирательные кампании не являлись самостоятельным объектом исследования. Опыт участия донского электората на выборах в Государственную думу, социокультурный облик первых избирателей в ОВД, выборные технологии, применяемые политическими партиями в донской провинции практически не отражены в литературе.

В связи с этим представляется важным исследовать опыт проведения выборных кампаний в таком специфическом регионе Российской империи, каким была Область войска Донского. Донской регион оценивался властями как оплот монархизма и консерватизма, где решающую роль должна была сыграть такая особая электоральная группа, как казачество. Нами предпринята попытка выявления особенностей выборов в Государственную думу I и II созывов на Дону. Выборная кампания в Государственную думу в Донской области конкретизирует понимание выборного процесса как части политического процесса и формирования демократической культуры в России начала XX в.

Важным направлением анализа истории выборов в ОВД является изучение политизации различных слоев российского электората. Именно в этот период население Донской области вовлекалось в политический процесс через выборную кампанию. Отношение масс к опыту участия в выборах может быть оценено степенью их активности. Огромное значение имеет изучение местного политического ландшафта, формирования политических пристрастий донского электората и факторов, определяющих их выбор.

Выборы в Государственную думу активизировали деятельность всех политических сил Российской империи. Область войска Донского, несмотря на свою провинциальность, тоже не была исключением. Роль политических партий на выборах в ОВД включает выявление разных аспектов их влияния на выборный процесс в Государственную думу в целом и прежде всего на электорат, с точки зрения их политических предпочтений, принадлежности к определённым политическим партиям или наличия симпатии тем или иным политическим силам, представленным в Донском регионе.

Политическая борьба в ходе выборов в Государственную думу Первого и Второго созывов представляет интерес еще и в связи с тем, что в России совпадал процесс формирования партийной системы с процессом политизации общества в целом через выборы в Государственную Думу.

Область войска Донского на всех думских выборах представляла собой отдельный избирательный округ, от которого избирались 12 думских депутатов. Более того, Ростов-на-Дону в Думах I и II созывов вошел в число городов, получивших прямое думское представительство. Донская область с учетом сословной специфики региона, кроме трех обычных общероссийских курий (кре- стьянской, землевладельческой и городской) могла формировать еще и четвертую - казачью.

Процентное соотношение выборщиков по округам было следующим: 7,9\% от крестьянской курии, 26,6 \% от землевладельцев, 20,9\% от городской курии и $44 \%$ от казачества $[13$, л. 10] Отчасти курии землевладельцев и горожан состояли тоже из казаков. Избирательный закон гарантировал преимущество в составе избранных депутатов военно-служилому, казачьему сословию. Власти рассчитывали на верноподданнические монархические и консервативные настроения казачества, представляя ему преимущество по сравнению с крестьянством. Исход выборов в Государственную Думу в Области войска Донского не вызывал опасений властей. В обществе преобладало мнение о реакционности казачества как органичной части государственного механизма, особенно после событий 1905 г.

После опубликования законов от 6 августа 1905 г. городские управы начали составлять списки избирателей и публиковать их в газете «Донские областные ведомости». Граждан, наделенных гражданскими правами, было немного. Несмотря на разрешение проводить предвыборные кампанию, они не имели права собираться для обсуждения вопросов предвыборной тактики. Не следует игнорировать тот факт, что, Область войска Донского с декабря 1905 г. находилась на военном положении и шесть условиях усиленной чрезвычайной охраны. После принятия законов по выборам в Думу от 11 декабря 1905 г. и от 20 февраля 1906 г. число избирателей на Дону увеличилось, но цензовые ограничения сохранились. В соответствии с дополнением законодательства о выборах в них могли принимать участие от Области шесть выборщиков из рабочих фабрично-заводской, горной и горнозаводской промышленности $[13$, л. 10].

Наибольшей активностью в предвыборной кампании отличалась часть городской интеллигенции. Основная масса избирателей не проявляла заметного интереса к выборам, особенно представители казачьей и землевладельческой курий. Просьбы и угрозы местных властей не переломили такое настроение [21, 18 марта]. Донской журналист С. Я. Арефин писал, что значительная часть донского электората с недоверием отнеслась к выборам и боялась голосовать, опасаясь репрессий со стороны властей. Им трудно было разобраться в сложном избирательном законе, правилах, касавшихся порядка выборов и их организации $[1$, с.149]. В некоторых городах кандидаты в выборщики не были намечены до последнего дня. Часть выборщиков по городской курии не получила избирательных повесток. Большинство выборщиков от Области было аполитично, не осознавало значения Думы и выборов, как возможности свободного волеизъявления граждан [18, с. 192-193].

Из 180 намеченных по области выборщиков 109 вообще не заявили о совей принадлежности к политическим партиям [16, л. 34]. Но при всей аполитичности крестьянских и казачьих выбор- 
щиков большинство было настроено оппозиционно, уклон был в левую сторону" [19, с. 162]. Выборщики землевладельцы в основном поддерживали октябристов, городские - конституционных демократов, но более 50 \% всех выборщиков не определились в политических пристрастиях. Как правило, избиратели ориентировались на личные качества кандидата, а не на их партийную принадлежность. Из 182 человек 2/3 участников областного избирательного собрания по выборам в Государственную думу идентифицировали себя как беспартийные. Исход выборов зависел от результатов борьбы за их голоса на последнем этапе выборов. Более $70 \%$ членов областного избирательного собрания были представителями донского казачества. И это заставило все политические партии в заключительный период агитационной кампании усилить внимание к казачьим проблемам и вариантам их решения.

Отделы местных монархических организаций на Дону выступили за неприкосновенность казачьего быта и сохранение всех привилегий казачества, их сословной обособленности. Поддерживали правые и охранительные, полицейские функции, которые выполняло казачество в период Первой русской революции [7]. Монархисты негативно относились к предоставлению казачеству самоуправления и введению земства на Дону. Правые партии считали, что победят, опираясь на поддержку правительства и местной администрации. Такого рода поддержка, несомненно, имела место, но не оказала желаемого результата. Она проявлялась в попытках местной администрации создать благоприятные условия для «правых» путем дискриминации в отношении оппозиционных партий: запретах и закрытии оппозиционных изданий (так были закрыты газеты либерального толка «Донская Речь», «Новочеркасский курьер», «Донская жизнь»), запрещении партийных собраний и агитации и даже арестах деятелей этих партий. Однако поддержка властей не компенсировала ее десицит у правых со стороны электората. Последний же складывался, как показывают выборы на Дону, в силу невнимания местными организациями правых партий интересов других, кроме выборщиков-землевладельцев, влиятельных на месте электоральных групп и прежде всего - казачества. Их программы были далеки от интересов Дона и казачества. Тактика блоков с местными отделениями других партий, прежде всего октябристов также кардинальным образом не изменила уровень авторитетности правых сил на выборах в первой выборной кампании.

Программа Донского отдела «Союза 17 октября» мало касалась Дона и казачества. Организации октябристов сосредоточились на критике партий крайне левой ориентации, выпустив из вида кадетов и тем самым допустили тактический просчет в борьбе за голоса избирателей [17, c. 44]. В силу нечеткости идеологических установок октябристы не смогли создать устойчивую организационную структуру на Дону.

Выявляя влияние политических партий на ход выборов на Дону источники показывают, что каде- ты имели самый широкий электорат, завоевывая его с необыкновенным искусством приспособления к донскому политическому ландшафту, использования особенностей менталитета различных слоев местного электората. Донские кадеты были готовы создать в Ростове блок с левыми силами на период предвыборной борьбы. Однако социал-демократы не пошли на союз с либералами, обвинив их в стремлении использовать Думу для свертывания революции и поворота в русло реформ [20, 5 февраля]. Да и сами кадеты, будучи сторонниками реформаторского пути развития России, заявили о желании создать единый предвыборный левый блок, по политическим соображениям, чтобы предстать защитниками народных интересов [8, л. 8]. На выборах кадеты делали акцент на решении местных донских вопросов, требовали «раскрепощения» казачества, облегчения тяжести воинской повинности [21, 25 марта]. Они выступали за предоставление широкого самоуправления Донской области, против использования казаков для внутренней службы и выполнения ими полицейских обязанностей. В то же время они настаивали на сохранении казачества как самостоятельной этносословной общности. В земельном вопросе выдвигалось требование передать станицам для распределения между казаками земель войскового запаса и земель, находящихся под частным коннозаводством [21, 25 марта]

Левые политические силы видели в казачестве силу, враждебную освободительному движению, и вообще не учитывали в своих программах специфических казачьих интересов. Деятельность социал-демократов в ОВД сосредоточилась в Ростовском и Таганрогском гражданских округах, именно в них была наибольшая концентрация рабочих.

Таким образом, донские кадеты в большей степени, чем другие партии, выражали интересы основной части казачества. Кадеты не ограничивались близостью социально-классовой идентичности при завоевании на свою сторону сочувствующих, привлекая электоральные группы различной социальной и этнокультурной принадлежности. Они удачнее других использовали газеты, как канал влияния на различные слои населения донского общества, за что сотрудники оппозиционных изданий облагались штрафами и подвергались судебным преследованиям [23, л. 19].

9 апреля 1906 г. выборщики депутатов в Государственную думу от Области войска Донского собрались в Новочеркасске. В своем большинстве, кроме представителей городов, не имели четкой политической ориентации, не причисляли себя ник каким политическим партиям, но их настроения в основном были стихийно либеральными. Ни одна политическая партия не представляла большинства в областном избирательном собрании. В этих условиях многое зависело от того, какую позицию займут беспартийные выборщики, в первую очередь казаки. Для них наиболее существенным оказались сословная, национальная принадлежность и ораторские способности кандидатов, нежели их партийность. Казаки-вы- 
борщики отдавали предпочтение только тем кандидатам, которые были казаками, и никогда не выбирали инородцев, в честности, евреев, и иноверцев $[19$, с. 176$]$.

Кадеты на последнем этапе предвыборной борьбы показали себя опытными тактиками и смогли перетянуть на свою сторону казацкое большинство беспартийных казаков - выборщиков. В итоге оппозиционная правительству часть донского общества смогла провести своих кандидатов в Первую думу.

Всего от Области войска Донского было избрано 12 депутатов: 7 беспартийных, и 5 кадетов. По сословной принадлежности 10 были казаками, 1 - от крестьян и 1 - от городской интеллигенции [2, с. 85-96]. Из 7 беспартийных донских думцев в период работы в ней 6 казаков вошли во фракцию мирного обновления, 1 (крестьянин) - в «Трудовую группу" [26, с. 50].

В выборах во вторую Думу участвовали все политические силы, функционирующие на Дону. Большевики отказались от тактики бойкота, чтобы использовать думскую трибуну для пропаганды своих взглядов. Однако, считали, что добиться свободы парламентским путем невозможно, пока власть находится в руках царского правительства.

Перед выборами партии по-своему оценивали будущие результаты. Правы считали, что победят опираясь на поддержку правительства и местной администрации $[9$, л. 6]. Часть организаций октябристов эволюционировала вправо и, как правые монархические организации, стала причислять себя к «охранительным силам». Члены Таганрогского и Ростовского городских отделов «Союза 17 октября», в руководстве которых преобладали правые октябристы, выступали правым предвыборным блоком с «Союзом истинно русских людей» [22, 21 января]. В Новочеркасске октябристы не пошли на союз с правыми и выступали на выборах самостоятельно.

Решение большевиков участвовать в выборах побудило донской отдел кадетской организации учитывая обстановку репрессией со стороны администрации, пойти на сотрудничество с левами. Они предложили заключить единый левый блок на период предвыборной кампании. Кроме того, кадеты полагали, что два левых списка выборщиков в думу не пройдут. Несмотря на негативное отношение большевиков к сотрудничеству с кадетами, в документах донского департамента полиции, местной прессе имеются сведения об их совместной предвыборной деятельности. В Ростов состоялось общее предвыборное собрание социал-демократов и кадетов. На нем присутствовало 63 человека: 23 социал-демократа и 40 кадетов [10, л. 7]. Социал-демократы заявили, что совместный блок заключили только на время предвыборной кампании с целью противовеса местным черносотенцам. После заключения соглашения они должны были получить из 80 мест выборщиков - 30 для избрания одного депутата от Ростова-на-Дону, «Союз еврейского равноправия», по политическим взглядам близкий к либералам, - 8, остальные места выборщиков кадеты $[16$, л. 3]. Новочеркасский комитет кадетской партии тоже вступил в соглашение с левыми. Места кандидатов в выборщики по городской курии Черкасского округа в результате договоренности распределились следующим образом: 3 - социал-демократам, 3 - кадетам и 1 - эсерам $[16$, л. 3-4]. Но Ростовский и Новочеркассский блоки оказались не прочными. В Новочеркасске соглашение было разорвано до начала выборов выборщиков. В Ростове предвыборный блок просуществовал дольше, на выборы выборщиков кадеты и левые шли вместе как оппозиционная группировка, которые называли себя прогрессистами. Но сразу после выборов городских выборщиков блок распался по инициативе кадетов, которые получили большее количество голосов [20, 5 февраля]

Предвыборная кампания во вторую Государственную думу на Дону проходила в неблагоприятных для оппозиционных партий условий. Местная администрация стремилась закрыть левым и кадетам доступ во Вторую думу. Власти применяли репрессии, запретили проводить предвыборные собрания, вести предвыборную агитацию. Наиболее сильными административные притеснения были в донских городах. В Ростове за четыре дня с 7 по 11 января 1907 г. арестовали свыше 300 человек [20, 5 февраля]. Из 16 тысяч не доставили 3517 избирательные повестки, а 237 вообще исчезли [16, л. 5]. В Новочеркасске избиратели не получили свыше 600 избирательных приглашений. В Таганроге 1000 повесток из 4000 не дошли до адресатов [25, с. 509]. Администрация запрещала выход оппозиционных изданий, как это было, например, в Ростове $[11$, л. 9]. Такими мерами, по признанию градоначальника Ростова, власти пытались создать для правых благоприятные условия на выборах. В фондах департамента полиции сохранились сведения об отклонении местной администрацией просьбы Донского отдела конституционно-демократической партии разрешить предвыборную агитацию по той причине, что кадеты разовьют бурную деятельность и поручиться за результаты выборов будет невозможно [15, л. 5]. За девять дней до начала выборов по округам Донской области ни одна партия не опубликовала списков своих кандидатов в выборщики. В большинстве станиц и волостей предвыборные собрания казаков и крестьян были запрещены [22, 12 января, 28 января, 12 февраля].

Разрешение на проведение предвыборной кампании было получено на Дону за неделю до выборов. В основном организаторами, так называемых, внепартийных собраний были члены кадетской партии, основное внимание они уделяли избирателям городских съездов. В Новочеркасске кадетским лидерам удалось подготовить и провести четыре внепартийных предвыборных собрания городских избирателей. На собрании, состоявшемся 19 января 1907 г., в котором участвовало более 1400 человек, было заявлено, что на выборы кадеты и левые идут единым 
«прогрессивным» блоком». В Таганроге кадеты и октябристы провели три совместных предвыборных собрания. Удалось провести предвыборные собрания городских избирателей в станицах Каменской (Донецкий округ), Урюпинской и Константиновской. Их организаторами были кадеты, они провели своих кандидатов в выборщики по городским куриям этих округов Донской области [14, л. 1,10$]$

В ходе предвыборной борьбы представители политических партий не пренебрегали никакими средствами, вплоть до доносов, подкупов и клеветы. В Документах департамента полиции упоминается о том, что кадеты в Таганроге обещали дать деньги социал-демократам, если те продадут кадетам несколько мест выборщиков во Вторую думу $[12$, л. 37]. Ростовские кадеты по сведениям того же департамента полиции потратили на выборах до 50 тысяч рублей на подкуп, покупку избирательных бюллетеней [14, л. 10]. Октябристы в Таганроге, «Союз истинно русских людей» в Ростове и кадеты в Новочеркасске использовали практику рассылки готовых избирательных бюллетеней с фамилиями своих кандидатов, а в день выборов выборщиков, нарушая избирательный закон, передавали отпечатанные заранее избирательные записки лицам, имеющим право участвовать в выборах. В день выборов членов Государственной думы в Новочеркасске кадеты в центре города организовали нелегальные канцелярии для офрормления и раздачи избирательных бюллетеней $[14$, л.1, 10]. Представители ростовского отдела «Союза истинно русских людей» и «Союза 17 октября» предлагали редакции прокадетского издания «Приазовский край» большое вознаграждение за публикацию списка кандидатов в выборщики и выборные воззвания своих организаций

Несмотря на противодействия администрации и полиции, предвыборная агитация и пропаганда велась на Дону довольно активно. В результате оппозиционные партии мобилизовали свой перводумский электорат. Однако избиратели казачьей и землевладельческой курий по-прежнему были пассивны. Общим с предыдущей предвыборной кампанией было незнание избирателями выборных технологий, неосведомленность в избирательном законе

Политический портрет донского выборщика позволяет выяснить популярность действующих политических партий среди различных категорий жителей Донской области. Особенностью вторых выборов на Дону была возросшая политизация избирателей по городской курии. Процент партийных кадетских бюллетеней поднялся с 30-40 \% (выборы в Первую думу) до 85 \% [22, 24 апреля]. Городская курия осталась базовой для кадетов $(64,8 \%)$. В 5 из 9 округов Донской области кадеты провели своих кандидатов, именно там они имели свои организации и возможность вести активную агитационную работу. Успеху кадетских кандидатов, способствовало наличие среди них незаурядных людей, пользующихся доверием и популярностью среди донских жителей. Избира- тели городской курии не дали ни одного места выборщиков партиям, стоящим правее прогрессистов. Однако городская курия дала только $20,9 \%$ выборщиков областного избирательного собрания. Решающее влияние на ход выборов оказывали курии казачья и землевладельцев. Причем, 78,7 \% выборщиков по курии землевладельцев принадлежали правым и беспартийным, примыкающим к правым. 61 из 79 выборщиков - казаков были беспартийными и симпатизировали, как правило, правым париям ${ }^{1}$. Большинство выборщиков по крестьянской курии (12 из 14) не имели четкой политической ориентации, пристрастия определялись на последней стадии выборов. Все выборщики по рабочей курии - были социал-демократами

Партийный состав донских выборщиков выглядел так: 34 кадета, 20 прогрессистов, 4 «левых», 21 - беспартийные, примыкающие к «левым», 78 - беспартийные, примыкающие к «правым», 17 - «правых», 2 - беспартийные, без определенно выраженных политических симпатий.

Итог выборов зависел от беспартийных выборщиков. Большинство из них: станичная администрация, землевладельцы, рядовые казаки - симпатизировали «правым». Лишь казачья интеллигенция придерживалась оппозиционных, либеральных взглядов. Но казаки, как уже отмечалось выше, больше интересовались не политикой, а личностями и в конечном итоге голосовали в зависимости от личных симпатий.

Усилия кадетов на последнем этапе предвыборной борьбы увенчались успехом. Если изначально большинство беспартийных выборщиков ориентировались на правых, то накануне выборов кадеты перетянули их, в том числе казаков, на свою сторону. В результате более 100 выборщиков в последний момент перешли на сторону оппозиции и голосовали за левых и кадетских кандидатов. Конституционные демократы и представители левых партий в ночь перед выборами депутатов Думы заключили тайное соглашение с частью казачьих и крестьянских выборщиков. Депутатские места в результате такого соглашения предполагалось распределить следующим образом: 1 место - представителям рабочих, 3 казакам, 4 - кадетам и 1 - крайне «левым» [14, л. 4-6]. В итоге, при избрании депутатов Второй Государственной думы от Области войска Донского оппозиционные силы победили на выборах правых.

Из 12 депутатов 10 были от партии кадетов, 1 - от социал-демократов, 1 - беспартийный, «левый». Представители правых партий не получили ни одного места. 9 депутатов из 12 были казаками.

Успеху кадетской партии способствовали: умелая организация предвыборной борьбы, дополнение местными требованиями общеполитической части программы, разрозненность политических противников, прежде всего правых, их неумение

1 Подсчеты сделаны на основании данных фондов окружных комиссий по делам о выборах в Государственную думу за 1905-1912 гг. в Области войска Донского ГАРО. Ф.431 - 440. 
организовать и эфффективно провести предвыборную кампанию. Победа кадетов на Дону была следствием привлекательности их политического курса для казаков и авторитета местных лидеров партии, которые пользовались в это время доверием большей части населения Донской области. Выборы во ІІ Государственную думу подтвердили оппозиционность донского населения.

Выборы на Дону свидетельствуют о том, что в целом роль политических партий в борьбе за электорат, их влияние на формирование политических предпочтений избирателей проявлялась весьма отчетливо. Примеры, демонстрирующие ход предвыборной агитации в Донской области, в которой участвовали различные политические партии, со всей очевидностью раскрывают преимущества кадетов. Ее гибкость и эффективность обеспечивала им успех, особенно, во время первой выборной кампании, то есть при отсутствии конкуренции с социалистическими партиями Общей основой успеха кадетов были явно среди электората оппозиционные настроения. Кадеты смогли на последнем этапе предвыборной борьбы в ходе выборов и в I и во ІІ Государственные думы «перетянуть» беспартийный электорат на свою сторону и одержать победу. В отличие от других регионов страны, популярность кадетов не упала по сравнению с первой выборной кампанией в условиях конкуренции с социалистическими партиями, включившимися в предвыборную борьбу.

Местные кадетские организации отличались особой сплоченностью и спецификой состава Членство местной интеллигенции также способствовало завоеванию кадетами симпатий со стороны различных слоев донского электората, в том числе даже казаков, и крестьян, несмотря на то, что в основании этих групп, несомненно присутствовали черты антисемитизма и монархизма. Кадетам нельзя было игнорировать осо- бенности казачьей ментальности, в том числе, даже и националистические настроения. Региональная мимикрия политической платформы и гибкости учета социальной идентичности донского электората кадетов проявлялись в диапазоне от приятия «великорусского шовинизма» казачества и православия и народности крестьянства до поддержки национально-религиозных меньшинств, в том числе представленных местной интеллигенцией

История выборов в Области войска Донского демонстрирует процесс политизации населения, вовлеченного в избирательный процесс, прежде всего, в плане предпочтений выборщиков, которые часто не были оформлены, но четко проявлялись как проявление своих групповых интересов. Политические партии на Дону играли огромную роль в процессе вовлечения населения в избирательный процесс в плане его политизации. Все они вели предвыборную борьбу за избирателя, используя прессу, собрания, и даже «грязные технологии». Однако успех их влияния за вовлечение избирателя в орбиту своих политических интересов зависел от ряда обстоятельств. Оппозиционные настроения в обществе, характерные для основной массы донского электората, обеспечили преимущества пропаганде «оппозиционных партий». Далее, успех политических партий зависел от «чувствительности» их к групповым интересам донского электората, в первую очередь - казачьего. Решающую роль в борьбе политических партий за электорат, как свидетельствуют выборы на Дону, играла верно, выбранная тактика. На выборах в | и || Государственные думы в ОВД наиболее эффективной оказалась тактика кадетов. Однако, и социал-демократы, и октябристы, и правые боролись за голоса избирателей и, следовательно, воздействовали на процесс выбора избирателями депутатов Думы.

\section{Источники и литература}

1. Арефин С. Я. Донские казаки // Русское богатство. 1906. №12. С. 116-152.

2. Бийович М. М. Наши депутаты. Члены Государственной Думы. (Портреты и биографии). Первый созыв. Сост. М.М. Бийович. М: Тип. Т-ва И. Д. Сытина. 1906. 512 с.

3. Братолюбова М. В. Выборы в I Государственную думу в Области войска Донского // Научная мысль Кавказа 2004. №2. C. 53-61.

4. Братолюбова М. В. Парламентская деятельность российского казачества в начале XX века // Таврические чтения 2012. Актуальные проблемы парламентаризма: история и современность. СПб: ЭлекСис, 2013. С. 83-97.

5. Галий И. П. Партия «Союз 17 октября» в Донской области в 1905-1912 гг.: дис. ... канд. ист. наук. Ростов-на-Дону, 2005. 175 c.

6. Галич Ж. В., Деордиева А. Н. Либералы накануне и в годы революции. Ростов-на-Дону, 2017. 176 с

7. Голос Дона. 1906. №34.

8. Государственный архив Российской Федерации (далее - ГАРФ). Ф.102. Оп.4. Д.45. 4 І.

9. ГАРФ. Ф. 102. ОП.4. Д.45. Ч.9

10. ГАРФ. Ф.102. ДП. 4 дел-во. 1907. Д.45. Ч.11

11. ГАРФ. Ф.102. ДП. 4 дел-во. 1907. Д.45. Ч.8.

12. ГАРФ.Ф.102. ОП. $234-235$. Д.725. Ч.20. Д.4.

13. Государственный архив Ростовской области (далее - ГАРО). Ф.440. Оп.1. Д.335

14. ГАРО. Ф. 55. ОП.1. Д.297.

15. ГАРО.Ф.829.ОП.1. Д. 154.

16. ГАРО. Ф.826. Оп.2., Д.47.

17. Забелин В. М. Политически партии на Ставрополье и Кубани в 1905-1907 гг. СПб: Нестор, 1998. 45 с

18. Крюков Ф. Д. Встреча // Русское богатство. 1906. Ноябрь. С.116-152. 
19. Крюков Ф. Д. Выборы на Дону // К 10-летию І-ой Государственной Думы. 27 апреля 1906 - 17 апреля 1916 г. Сборник статей перводумцев. Пг:: [б.и.], 1916.

20. Новочеркасский курьер. 1907.

21. Приазовский край. 1906.

22. Приазовский край. 1907.

23. Российский государственный исторический архив. Ф.776. Оп.16. Ч.1. Д.343.

24. Сватиков С. Г. Россия и Дон. Исследование по истории государственного и административного права и политических движений на Дону (1549-1917). Белград: Издание Донской исторической комиссии, 1924. 592 с.

25. Скорик А. П., Панкова-Козочкина Т. В. Первые шаги Донской кадетской партии // Вопросы истории. 2004. №12. C.135-142.

26. Состав Трудовой группы в I и II Государственной Думе. Сводная таблица членов фракции. Ин-т истории СССР / авт. вступ. ст. и сост. Д. А. Колесниченко. М.: Ин-т истории СССР, 1988. 122 с.

\section{References}

1. Arefin S. Ya. Donskie kazaki (The Don Cossacks) // Russkoe bogatstvo. 1906. No.12. P. 116-152. (In Russian).

2. Bijovich M. M. Nashi deputaty. CHleny Gosudarstvennoj Dumy. (Portrety i biografii). Pervyj sozyv. (Our deputies. Members of the State Duma. (Portraits and biographies). First convocation) / collected be M. M. Bijovich. Moscow: I. D. Sytin's publishing house, 1906. 512 p. (In Russian).

3. Bratolyubova M. V. Vybory v I Gosudarstvennuyu dumu v Oblasti vojska Donskogo (Elections to the I State Duma in the Region of the Don Cossack Host) // Nauchnaya mysl' Kavkaza. 2004. No. 2. P. 53-61. (In Russian)

4. Bratolyubova M. V. Parlamentskaya deyatel'nost' rossijskogo kazachestva v nachale XX veka (Parliamentary activity of the Russian Cossacks in the beginning of the XX century) // Tavricheskie chteniya 2012. Aktual'nye problemy parlamentarizma: istoriya i sovremennost'. St. Petersburg: EHlekSis, 2013. P. 83-97. (In Russian).

5. Galij I. P. Partiya "Soyuz 17 oktyabrya» v Donskoj oblasti v 1905-1912: "The Union of October 17" party in the Don region in 1905-1912): thesis. Rostov on Don, 2005. 175 p. (In Russian).

6. Galich Zh. V., Deordieva A. N. Liberaly nakanune i v gody revolyucii. (Liberals on the eve of and in days of revolution). Rostov on Don, 2017. 176 p. (In Russian).

7. Golos Dona. 1906. No. 34. (In Russian).

8. Gosudarstvennyj arhiv Rossijskoj Federacii (GARF). F.102. Inv.4. D.45. CH I. (In Russian).

9. GARF. F. 102. Inv.4. D.45. CH.9. (In Russian).

10. GARF. F.102. Inv. 4 del-vo. 1907. D.45. CH.11. (In Russian)

11. GARF. F.102. Inv. 4 del-vo. 1907. D.45. CH.8. (In Russian).

12. GARF.F.102. Inv.234-235. D.725. CH.20. D.4. (In Russian).

13. Gosudarstvennyj arhiv Rostovskoj oblasti (GARO). F.440. Inv.1. D.335. (In Russian).

14. GARO. F. 55. Inv.1. D.297. (In Russian).

15. GARO.F.829. Inv.1. D. 154. (In Russian).

16. GARO. F.826. Inv.2. D.47. (In Russian).

17. Zabelin V. M. Politicheski partii na Stavropol'e i Kubani v 1905-1907gg. (Political parties on the Stavropol Territory and Kuban in 1905-1907). St. Peterburg: Nestor, 1998. 45 p. (In Russian).

18. Kryukov F. D. Vstrecha (Meeting) // Russkoe bogatstvo. 1906. November. P. 116-152. (In Russian).

19. Kryukov F. D. Vybory na Donu (Elections on the Don) // K 10-letiyu I-oj Gosudarstvennoj Dumy. 27 aprelya $1906-17$ aprelya $1916 \mathrm{~g}$. Sbornik statej pervodumcev. Petrograd, 1916. (In Russian).

20. Novocherkasskij kur'er. 1907. (In Russian).

21. Priazovskij kraj. 1906. (In Russian).

22. Priazovskij kraj. 1907. (In Russian)

23. Rossijskij gosudarstvennyj istoricheskij arhiv (RGIA). F.776. Op.16. CH.1. D.343. (In Russian)

24. Svatikov S. G. Rossiya i Don. Issledovanie po istorii gosudarstvennogo i administrativnogo prava i politicheskih dvizhenij na Donu (1549-1917). (A Research in the History of the State and Administrative Law and Political Movements on the Don (1549-1917). Belgrad: Izdanie Donskoj istoricheskoj komissii. 1924. 592 p. (In Russian).

25. Skorik A. P., Pankova-Kozochkina T. V. Pervye shagi Donskoj kadetskoj partii (First steps of the Don cadet party) /I Voprosy istorii. 2004. No. 12 P. 135-142. (In Russian).

26. Sostav Trudovoj gruppy v I i II Gosudarstvennoj Dume. Svodnaya tablica chlenov frakcii. (The Structure of Labour Group in I and /I State Dumas. Summary Table of Faction Members). Moscow: Institute of History of USSR publ., 1988. 122 p. (In Russian). 